\title{
PENGARUH KEBIJAKAN TAX AMNESTY, KESADARAN WAJIB PAJAK DAN SANKSI PAJAK TERHADAP KEPATUHAN WAJIB PAJAK ORANG PRIBADI DI KPP PRATAMA MANADO
}

\author{
Elisabeth Nadia Rorong ${ }^{1}$, Lintje Kalangi ${ }^{2}$, Treesje Runtu ${ }^{3}$ \\ 1,2,3 Jurusan Akuntansi, Fakultas Ekonomi Dan Bisnis, Universitas Sam Ratulangi Manado, Alamat: Kampus \\ UNSRAT, Kota Manado, Kode Pos , Indonesia \\ E-mail : lisa.11463@gmail.com
}

\begin{abstract}
The purpose of this study is to analyze the effect of tax amnesty policy, taxpayer awareness and tax sanctions on taxpayer compliance of individuals in KPP Pratama Manado. The Population in this study is all Individual Taxpayers registered pursuant to tax amnesty policy in KPP Pratama Manado. The number of samples in this study were 30 respondents in Manado area. Sampling was done by using Purposive Sampling Method. Methods Data analysis used in this research is validity test, reliability test, classical assumption test, multiple regression analysis, determination coefficient ( 22 test), regression test ( $F$ test), and partial regression test ( $t$ test). Based on the results of data analysis, it is known that tax amnesty has a positive effect on taxpayer compliance. Result of t test show value t count 3,956> t table 1,708 with significance value $(0,01)<0,05$ so that H1 accepted. Awareness of taxpayers does not significantly affect taxpayer compliance. The result of t test shows $t$ value $(-790)<t$ table 1,708 with significance value $(0,437)>0,05$ so that $\mathrm{H} 2$ is rejected. Tax sanctions have no positive effect on taxpayer compliance. The result of $t$ test shows $t$ value $(-2,167)<t$ table 1,708 with significance value $(0,04)<0,05$ so that H3 is rejected. Variable tax amnesty, taxpayer awareness and tax sanction can be used to explain compliance of taxpayers by $45 \%$.
\end{abstract}

Keywords: tax amnesty, taxpayer awareness, tax sanction, and taxpayer compliance

\section{PENDAHULUAN}

Peraturan perundang-undangan perpajakan terus disempurnakan seiring dengan perkembangan ekonomi, teknologi informasi, sosial dan politik. Perubahan perundangundangan perpajakan khususnya undang-undang tentang ketentuan umum dan tata cara perpajakan dimaksudkan untuk lebih memberikan keadilaan, meningkatkan pelayanan kepada wajib pajak, meningkatkan kepastian dan penegakkan hukum, meningkatkan keterbukaan administrasi perpajakan, dan meningkatkan kepatuhan wajib pajak. Sistem, mekanisme, dan tata acara pelaksanaan hak dan kewajiban perpajakan yang sederhana menjadi ciri dan corak dalam perubahan undang-undang ini dengan tetap menganut self assessment system.

Kebijakan perpajakan juga merupakan suatu bentuk dari reformasi perpajakan. Tax Amnesty merupakan salah satu kebijakan dibidang perpajakan yang dilaksanakan oleh Dirjen Pajak. Pengampunan Pajak atau Tax Amnesty adalah penghapusan pajak yang seharusnya terutang, tidak dikenai sanksi administrasi perpajakan dan sanksi pidana di bidang perpajakan, dengan cara mengungkap harta dan membayar uang tebusan sebagaimana diatur dalam Undang-Undang Nomor 11 Tahun 2016 tentang Pengampunan Pajak. Tujuan dari pengampunan pajak adalah untuk mempercepat pertumbuhan dan restrukturisasi ekonomi melalui pengalihan harta, yang akan berdampak pada peningkatan likuiditas domestik, perbaikan nilai tukar Rupiah, penurunan suku bunga, dan peningkatan investasi. Mendorong reformasi perpajakan menuju sistem perpajakan yang lebih berkeadilan serta perluasan basis data perpajakan yang lebih valid, komprehensif, dan terintegrasi, selain itu juga untuk 
meningkatkan penerimaan pajak juga merupakan tujuan dari pengampunan pajak (UU No.11 Tahun 2016).

Upaya pemerintah menarik dana masyarakat yang selama ini parkir di perbankan negara lain merupakan tujuan dari pemberian tax amnesty (Yudhistira, 2014). Tax Amnesty merupakan hak para wajib pajak yang boleh dimanfaatkan ataupun tidak. Wajib pajak yang mengungkap harta dan membayar uang tebusan diberi pengampunan (Yustinus, 2016). Berbagai upaya dalam membangun kemauan wajib pajak untuk mengikuti Tax Amnesty telah dilakukan Direktorat Jenderal Pajak. Sosialisasi mengenai Tax Amnesty telah dilakukan pemerintah melalui media elektronik dan cetak guna menarik kemauan wajib pajak mengikuti Tax Amnesty.

Pemberian sanksi wajib pajak yang tidak memenuhi kewajibannya sesuai dengan ketentuan peraturan perundang-undangan perpajakan yang berlaku merupakan sanksi perpajakan. Sanksi mengenai Tax Amnesty bagi wajib pajak diatur dalam Pasal 18 UU No.11 Tahun 2016. Sanksi administrasi berupa kenaikan sebesar 200\% (dua ratus persen) diberikan kepada wajib pajak yang belum atau kurang mengungkap hartanya dalam Surat Pernyataan sampai dengan akhir periode Tax Amnesty. Terdapat pula sanksi bagi wajib pajak yang memilih tidak ikut Tax Amnesty, jika terdapat harta yang diperoleh sejak 1 Januari 1985 sampai dengan 31 Desember 2015 dan belum dilaporkan dalam SPT Tahunan PPh, dianggap tambahan penghasilan dan dikenai pajak dan sanksi sesuai Undang-Undang (UU) yang berlaku. Berdasarkan uraian pada latar belakang maka perumusan masalah yang akan di bahas dalam penelitian ini adalah sebagai berikut:

1. Apakah Tax Amnesty berpengaruh terhadap Kepatuhan Wajib Pajak?

2. Apakah Kesadaran Wajib Pajak berpengaruh terhadap Kepatuhan Wajib Pajak?

3. Apakah Sanksi Pajak berpengaruh signifikan terhadap Kepatuhan Wajib Pajak?

4. Apakah kebijakan Tax Amnesty, Kesadaran Wajib Pajak dan Sanksi Pajak berpengaruh secara simultan terhadap Kepatuhan Wajib Pajak?

Adapun tujuan dilakukan penelitian ini adalah untuk :

1. Untuk mengetahui pengaruh Tax Amnesty terhadap Kepatuhan Wajib Pajak Orang Pribadi di KPP Pratama Manado.

2. Untuk mengetahui pengaruh Kesadaran Wajib Pajak terhadap Kepatuhan Wajib Pajak Orang Pribadi di KPP Pratama Manado.

3. Untuk mengetahui pengaruh Sanksi Pajak terhadap Kepatuhan Wajib Pajak Orang Pribadi di KPP Pratama Manado.

4. Untuk mengetahui pengaruh kebijakan Tax Amnesty, Kesadaran wajib Pajak dan Sanksi Pajak secara simultan terhadap Kepatuhan Wajib Pajak Orang Pribadi di KPP Pratama Manado.

Hasil penelitian ini diharapkan dapat memberi manfaat antara lain:

1. Manfaat Teoritis

Dapat bermanfaat bagi pengembangan ilmu pengetahuan terlebih khusus di bidang ilmu akuntansi dan perpajakan dengan memberi gambaran mengenai pengaruh adanya kebijakan Tax Amnesty, Kesadaran Wajib pajak dan Sanksi Pajak dalam upaya meningkatkan Kepatuhan Wajib Pajak. Dan bisa dijadikan referensi bagi penelitian selanjutnya yang mengangkat permasalahan sehubungan dengan penelitian ini.

2. Manfaat Praktis

a. Bagi Kantor Pelayanan Pajak Pratama Manado penelitian ini memberikan informasi sehubungan dengan permasalahan Kebijakan Tax Amnesty, Kesadaran Wajib Pajak dan Sanksi Pajak yang mempengaruhi tingkat Kepatuhan Wajib Pajak.

b. Sebagai sarana penerapan ilmu pengetahuan yang telah diperoleh selama masa perkuliahan dan sumber informasi yang lebih luas mengenai perpajakan serta permasalahan yang ada di dalamnya. 


\section{TINJAUAN PUSTAKA}

\subsection{Pajak}

Menurut Sommerfeld, Anderson dan Brock Pajak adalah suatu pengalihan sumber dari sektor swasta ke sektor pemerintah, bukan akibat pelanggaran hukum, namun wajib dilaksanakan, berdasarkan ketentuan yang sudah ditentukan dan tanpa mendapat imbalan yang langsung dari proporsionalnya, agar pemerintah dapat melaksanakan tugas-tugasnya untuk menjalankan pemerintahan (Waluyo, 2011:2).

\subsection{Kepatuhan Wajib Pajak}

Menurut Kamus umum Bahasa Indonesia, istilah kepatuan adalah "Kepatuhan berarti tunduk atau patuh pada ajaran dalam perpajakan, kita dapat memberi pengertian bahwa kepatuhan perpajakan merupakan ketaatan, tunduk, dan patuh, serta melaksanakan ketentuan perpajakan. Jadi, Wajib Pajak patuh adalah Wajib Pajak yang taat dan mematuhi serta melaksanakan kewajiban perpajakan sesuai ketentuan peraturan perundang-undangan perpajakan.”(Ngadiman, 2015).

\subsection{Tax Amnesty}

"Tax amnesty is a term used to describe a one-time offer to settle an outstanding tax debt for an amount that is less than the current debt. In other words, this approach means enabling taxpayers to pay unpaid tax debts under suitable circumstances without incurring additional late fees and other penalties (Wisegeek, 2014)". Yang artinya Tax Amnesty adalah istilah yang digunakan untuk menggambarkan penawaran satu kali untuk menyelesaikan hutang pajak yang beredar dengan jumlah yang kurang dari hutang saat ini. Dengan kata lain, pendekatan ini berarti memungkinkan pembayar pajak untuk membayar hutang pajak yang belum dibayar dalam keadaan yang sesuai tanpa menimbulkan biaya keterlambatan tambahan dan denda lainnya. Penelitian dari Ngadiman dan Huslin (2015) mengenai tax Amnesty menunjukkan bahwa tax amnesty berpengaruh positif terhadap kepatuhan wajib pajak. Oleh sebab itu, tax amnesty diduga berpengaruh terhadap kepatuhan wajib pajak.

\subsection{Kesadaran Wajib Pajak}

Kesadaran perpajakan adalah suatu kondisi dimana seseorang mengetahui, mengakui, menghargai dan menaati ketentuan perpajakan yang berlaku serta memiliki kesungguhan dan keinginan untuk memenuhi kewajiban perpajakannya (Muliari, 2011). Kesadaran wajib pajak adalah suatu kondisi dimana wajib pajak mengetahui, memahami dan melaksanakan ketentuan perpajakan dengan benar dan sukarela. Menurut Soemarso(1998) dan Jatmiko (2006) menyatakan bahwa salah satu penyebab banyaknya potensi pajak yang tidak dapat dijaring adalah rendahnya kesadaran perpajakan masyarakat (Dewi \& Noviary, 2017). Dalam meningkatkan kepatuhan wajib pajak diperlukan adanya kesadaran perpajakan dari wajib pajak. ileh sebab itu, kesadaran wajib pajak diduga berpengaruh terhadap kepatuhan wajib pajak.

\subsection{Sanksi Pajak}

Sanksi adalah suatu tindakan berupa hukuman yang diberikan kepada orang yang melanggar peraturan. Peraturan atau Undang-undang merupakan rambu-rambu bagi seseorang umtuk melakukan sesuatu mengenai apa yang harus dilakukan dan apa yang seharusnya tidak dilakukan. Sanksi diperlukan agar peraturan atau undang-undang tidak dilanggar (Arum, 2012). Beberapa hasil penelitian yang dilakukan Renny (2013), Robert (2015) dan Ngadiman \& Huslin (2015) mengenai sanksi perpajakan menunjukan sanksi perpajakan berpengaruh positif terhadap kepatuhan wajib pajak. Oleh sebab itu, sanksi perpajakan diduga akan berpengaruh terhadap tingkat kepatuhan wajib pajak. 


\section{METODE PENELITIAN}

\subsection{Jenis dan sumber data}

Penelitian ini merupakan jenis penelitian deskriptif kuantitatif. Penelitian deskriptif meliputi pengumpulan data untuk diuji hipotesis atau menjawab pertanyaan mengenai status terakhir dari subjek penelitian (Kuncoro, 2013:12).Dalam penelitian terdapat dua sumber data data yang dapat diperoleh yaitu pertama data primer adalah sumber data yang diperoleh peneliti secara langsung dari sumber asli (tidak melalui perantara) berupa wawancara dan hasil pengisian kuisioner pada Wajib Pajak Orang Pribadi yang terdaftar di KPP Pratama Manado, Jl. Gunung klabat Manado. Kedua data sekunder adalah data yang telah diolah lebih lanjut menjadi bentuk-bentuk seperti tabel, gambar dan lain-lain. Selain itu ada data yang diperoleh melalui data dokumen, kepustakaan dan sumber tertulis lainnya berupa literature dan peraturan pemerintah yang memiliki memiliki hubungan dengan pokok bahasan yang telah diteliti.

\subsection{Sampel dan teknik pengambilan sampel}

Sampel adalah bagian dari jumlah dan karakteristik yang dimiliki oleh populasi. (Sangadji \& Sopiah, 2010: 186). Karena jumlah populasi yang banyak maka tidak semua anggota populasi dijadikan sampel penelitian. Sampel yang digunakan dalam penelitian ini adalah sebanyak 30 responden dengan pengambilan sampel menggunakan teknik Purposive Sampling yaitu sampel ditentukan sesuai dengan kriteria penelitian. Kriteria dalam penelitian ini adalah wajib pajak orang pribadi yang mengikuti tax amnesty; Wajib pajak orang pribadi dengan status pekerjaan sebagai Pegawai Negeri Sipil dan Karyawan Swasta.

\subsection{Metode analisis}

Pengolahan data dilakukan dengan cara menggunakan perhitungan 5 poin skala Likert, 1 STS hingga 5 SS dalam kuisioner yang diisi setiap reponden, kemudian dihitung dan diolah dengan menggunakan program Software Statistical Product and Service Solution (SPSS) versi 23 untuk menghasilkan perhitungan yang menunjukan pengaruh variable independen terhadap variable dependen. Metode Analisis data yang digunakan dalam penelitian ini yaitu, uji validitas, uji reliabilitas, uji asumsi klasik, analisis regresi berganda, koefisien determinasi (uji R2 ), uji regresi stimultan (Uji F), dan uji regresi parsial (uji t).

\section{HASIL ANALISIS DAN PEMBAHASAN}

\subsection{Hasil analisis}

Responden dalam penelitian ini yaitu wajib pajak orang pribadi yang terdaftar di KPP Pratama Manado dengan jumlah responden sebanyak 30 orang. 30 eksamplar kuesioner yang diberikan kepada responden telah diisi secara lengkap dan benar sehingga layak untuk dianalisis lebih lanjut untuk kepentingan penelitian ini. karakteristik responden dikelompokkan menurut usia, jenis kelamin, pekerjaan, pengalaman kerja, pendidikan terakhir, pengisian SPT dan pendidikan pajak.

\subsubsection{Uji Kualitas Data}

1. Uji validitas digunakan untuk mengukur sah/valid tidaknya suatu kuesioner sebagai instrument penelitian. Pada penelitian ini data yang digunakan dinyatakan valid. Hal ini dibuktikan melalui pengujian SPSS Version 23 dan ditunjukan pada Tabel 1. 


\section{Tabel 1 Hasil Uji Validitas}

\begin{tabular}{|c|c|c|c|c|}
\hline Variabel & Pertanyaan & r-Hitung & r-Tabel & Keterangan \\
\hline \multirow{5}{*}{ Tax Amnesty (X1) } & 1 & 0,389 & 0,361 & Valid \\
\hline & 2 & 0,666 & 0,361 & Valid \\
\hline & 3 & 0,436 & 0,361 & Valid \\
\hline & 4 & 0,503 & 0,361 & Valid \\
\hline & 5 & 0,525 & 0,361 & Valid \\
\hline \multirow{5}{*}{$\begin{array}{c}\text { Kesadaran Wajib Pajak } \\
\text { (X2) }\end{array}$} & 1 & 0,532 & 0,361 & Valid \\
\hline & 2 & 0,440 & 0,361 & Valid \\
\hline & 3 & 0,675 & 0,361 & Valid \\
\hline & 4 & 0,451 & 0,361 & Valid \\
\hline & 5 & 0,370 & 0,361 & Valid \\
\hline \multirow{5}{*}{ Sanksi Pajak (X3) } & 1 & 0,385 & 0,361 & Valid \\
\hline & 2 & 0,705 & 0,361 & Valid \\
\hline & 3 & 0,747 & 0,361 & Valid \\
\hline & 4 & 0,732 & 0,361 & Valid \\
\hline & 5 & 0,777 & 0,361 & Valid \\
\hline \multirow{5}{*}{$\begin{array}{c}\text { Kepatuhan Wajib Pajak } \\
\text { (Y) }\end{array}$} & 1 & 0,556 & 0,361 & Valid \\
\hline & 2 & 0,385 & 0,361 & Valid \\
\hline & 3 & 0,433 & 0,361 & Valid \\
\hline & 4 & 0,478 & 0,361 & Valid \\
\hline & 5 & 0,592 & 0,361 & Valid \\
\hline
\end{tabular}

Sumber: Data Olahan, 2017

Berdasarkan data yang sudah diolah, bisa dilihat pada Tabel 1, nilai r-tabel dengan $n=46$ dan pada signifikan 0,05 adalah sebesar 0,361 maka dapat disimpulkan bahwa hubungan antara pertanyaan dari variabel $\mathrm{X}$ dan $\mathrm{Y}$ adalah valid, karena nilai semua hubungan pertanyaan lebih dari 0,361 .

2. Uji reliabilitas bertujuan untuk mengetahui besarnya indeks instrument dari variabel kebijakan tax amnesty (X1), kesadaran wajib pajak (X2), sanksi pajak (X3) dan kepatuhan wajib pajak (Y).setelah dilakukan uji validitas dan diperoleh butir pertanyaan yang valid,selanjutnya dilakukan uji reliabilitas dengan menggunakan rumus Cronbach Alpha. Keputusan untuk mengetahui bahwa instrument adalah reliabel jika nilai Alpha > 0,6. Dari analisis dengan program SPSS diperoleh uji reliabilitas seperti pada Tabel 2 dibawah ini. 3.

Tabel 2 Hasil Uji Reliabilitas

\begin{tabular}{|c|c|c|c|}
\hline Variabel & Crobach Alpha & Standar & Keterangan \\
\hline Tax Amnesty & 0,662 & 0,6 & Reliabel \\
\hline $\begin{array}{c}\text { Kesadaran Wajib } \\
\text { Pajak }\end{array}$ & 0,651 & 0,6 & Reliabel \\
\hline Sanksi Pajak & 0,757 & 0,6 & Reliabel \\
\hline $\begin{array}{c}\text { Kepatuhan Wajib } \\
\text { Pajak }\end{array}$ & 0,621 & 0,6 & Reliabel \\
\hline
\end{tabular}

Sumber: Data Olahan 2017 
Dari Tabel 2 dapat dilihat bahwa hasil uji reliabilitas terhadap kuisioner pengukur variabel penelitian di atas menunjukan bahwa:

1) Variabel tax amnesty (X1) memiliki nilai Combrach-Alpha sebesar 0,662. Hasil uji reliabilitas variabel tax amnesty dinyatakan reliabel karena nilainya lebih besar dari 0,6 $(0,662>0,6)$.

2) Variabel kesadaran wajib pajak (X2) memiliki nilai Cobrach-Alpha sebesar 0,651. Hasil uji reliabilitas kesadaran wajib pajak dinyatakan reliabel karena lebih besar dari 0,6 $(0,651>0,6)$.

3) Variabel sanksi pajak (X3) memiliki nilai Cobrach-Alpha sebesar 0,757. Hasil uji reliabilitas sanksi pajak dinyatakan reliabel karena lebih besar dari $0,6(0,757>0,6)$.

4) Variabel kepatuhan wajib pajak memiliki nilai Cobrach-alpha sebesar 0,621. Hasil uji reliabilitas kepatuhan wajib pajak dinyatakan reliabel karena lebih besar dari $0,6(0,621$ $>0,6)$.

\subsubsection{Uji Asumsi Klasik}

1. Uji normalitas ini bertujuan untuk membuktikan bahwa data variabel bebas (X) dan data variabel terikat (Y) pada persamaan regresi yang dihasilkan berdistribusi normal atau berdistribusi tidak normal. Uji normalitas data pada penelitian ini dilakukan dengan menggunakan analisis grafik dan uji One-Sample Kolmogorov-Smirnov.

\section{Gambar 1 Uji Asumsi Klasik Normalitas}

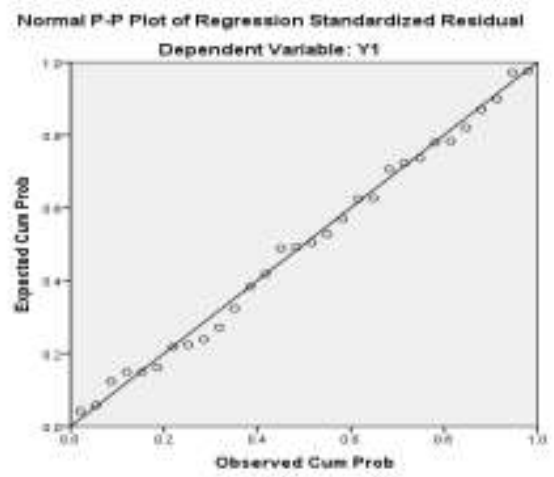

Sumber: Data Olahan, 2017

Berdasarkan Gambar 1 dapat dilihat bahwa data tersebar disekitar garis diagonal dan mengikuti arah garis diagonal, sehingga dapat dikatakan pola distribusinya normal.

\begin{tabular}{|cc|r|}
\hline \multicolumn{2}{|c|}{ One-Sample Kolmogorov-Smirnov Test } \\
\hline \multicolumn{2}{|c|}{} & $\begin{array}{c}\text { Unstandardized } \\
\text { Residual }\end{array}$ \\
\hline N & Mean & 46 \\
Normal Parameters ${ }^{\mathrm{a}, \mathrm{b}}$ & Std. Deviation & .0000000 \\
& Absolute & 2.67153325 \\
Most Extreme Differences & Positive & .108 \\
& Negative & .063 \\
& & -.108 \\
& Test Statistic & .108 \\
Asymp. Sig. (2-tailed) & $.200^{\mathrm{c}, \mathrm{d}}$ \\
\hline
\end{tabular}

a. Test distribution is Normal.

b. Calculated from data.

c. Lilliefors Significance Correction.

$\mathrm{d}$. This is a lower bound of the true significance. 
Berdasarkan Kolmogorov-Smirnov tampak bahwa nilai asymptotic significan adalah sebesar 0,200 > 0,05 yang menunjukkan bahwa nilai residual terdistribusi secara normal. Melihat grafik dan uji Kolmogorov-Smirnov diatas, dapat disimpulkan bahwa model regresi dalam penelitian ini dapat digunakan karena memenuhi asumsi normalitas.

2. Uji multikolinearitas dapat dilakukan dengan melihat nilai tolerance dan Variance Inflation Factor (VIF) dari hasil analisis dengan menggunakan SPSS. Apabila nilai tolerance value lebih tinggi daripada 0,10 atau lebih kecil daripada 10 maka dapat disimpulkan bahwa tidak terjadi multikolinearitas (Santoso, 2016). Hasil pengujian multikolinearitas dalam penelitian ini di sajikan sebagai berikut.

Tabel 3 Uji Multikolinearitas

\begin{tabular}{|c|c|c|}
\hline & \multicolumn{2}{|c|}{ Collinearity Statistics } \\
\hline & Tolerance & VIF \\
\hline X1 Tax Amnesty & .307 & 3.260 \\
\hline X2 Kesadaran Wajib Pajak & .697 & 1.436 \\
\hline X3 Sanksi Pajak & .373 & 2.681 \\
\hline
\end{tabular}

Dependent Variable: Y Kepatuhan Wajib Pajak

Sumber: Data Olahan 2017

Dari Tabel 3 dapat dilihat bahwa hasil uji multikolinearitas antar variabel bebas menunjukan bahwa nilai Variance Inflation Factor (VIF) masing-masing variabel bebas tidak lebih dari 10 yaitu:

- Variabel tax amnesty (X1) memiliki nilai Variance Inflation Factor (VIF) sebesar 3,260 atau tidak lebih dari 10. Maka dapat dikatakan variabel tax amnesty tidak terjadi multikolinearitas.

- Variabel kesadaran wajib pajak (X2) memiliki nilai Variance Inflation Factor (VIF) sebesar 1,436 atau tidak lebih dari 10. Maka dapat dikatakan variabel kesadaran wajib pajak tidak terjadi multikolinearitas.

- Variabel sanksi pajak (X3) memiliki nilai Variance Inflation Factor (VIF) sebesar 2,681 atau tidak lebih dari 10. Maka dapat dikatakan variabel kesadaran wajib pajak tidak terjadi multikolinearitas.

3. Uji heteroskedastisitas dapat diartikan sebagai ketidaksamaan variasi variabel pada semua pengamatan dan kesalahan yang terjadi memperlihatkan hubungan yang besarnya satu atau lebih variabel bebas sehingga kesalahan tersebut tidak random (acak). Untuk mendeteksi ada tidaknya heteroskedastisitas, dapat dilakukan dengan melihat ada tidaknya pola tertentu pada grafik plot (scatter plot). Jika tidak membentuk suatu pola, berarti bebas heteroskedastisitas.

\section{Gambar 2 Uji Heteroskedistisitas}

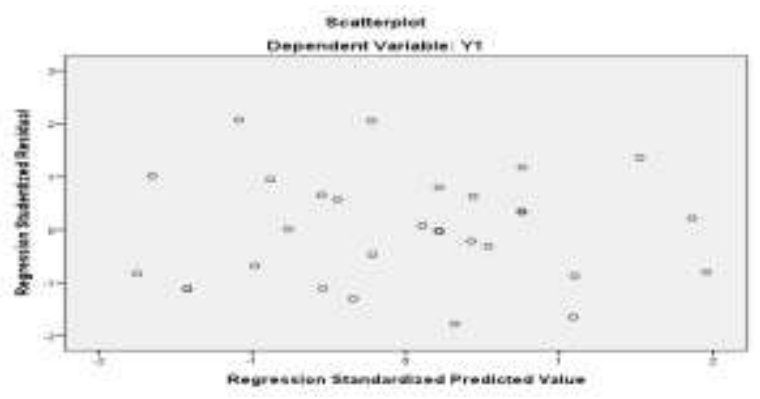

Sumber: Data Olahan, 2017 
Dari Gambar 2 dapat dilihat dalam persamaan regresi tidak terdapat heteroskedastisitas. Hal ini terlihat dari penyeberan titik-titik yang tidak memiliki pola yang jelas, serta titik-titik tersebut menyebar diatas dan di bawah angka 0 pada sumbu $\mathrm{Y}$, sehingga pada persamaan ini tidak terjadi heteroskedastisitas. Dan guna memastikan keakuratan gambar grafik plot diatas selanjutnya dilakukan Uji Gletser. Berikut hasil Uji Gletser dari output SPSS 23 disajikan secara ringkas pada tabel di bawah ini.

\section{Tabel 4 Uji Heteroskedastisitas (Glesjer)}

Coefficients $^{\mathrm{a}}$

\begin{tabular}{|c|c|c|c|c|c|}
\hline \multirow[b]{2}{*}{ Model } & \multicolumn{2}{|c|}{$\begin{array}{l}\text { Unstandardized } \\
\text { Coefficients }\end{array}$} & \multirow{2}{*}{$\begin{array}{c}\begin{array}{c}\text { Standardized } \\
\text { Coefficients }\end{array} \\
\text { Beta }\end{array}$} & \multirow[b]{2}{*}{$t$} & \multirow[b]{2}{*}{ Sig. } \\
\hline & $\mathrm{B}$ & Std. Error & & & \\
\hline (Constant) & 17.993 & 3.316 & & 5.426 & .000 \\
\hline X1 Tax Amnesty & .698 & .176 & 1.039 & 3.956 & .001 \\
\hline $\begin{array}{c}\text { X2 Kesadaran Wajib } \\
\text { Pajak }\end{array}$ & -.115 & .146 & -.138 & -.790 & .437 \\
\hline X3 Sanksi Pajak & -.351 & .162 & -.516 & -2.167 & .040 \\
\hline
\end{tabular}

Dari tabel 4 dapat dlihat bahwa terjadi heteroskedastisitas di dalam model regresi ini yaitu pada variabel kesadaran wajib pajak dan sanksi pajak yang digunakan dalam penelitian ini yang memiliki nilai signifikan lebih dari 0,05 .

\subsubsection{Analisis Regresi Linear Berganda}

Regresi linear berganda digunakan untuk mengetahui apakah tax amnesty, kwsadaran wajib pajak dan sanksi pajak berpengaruh terhadap kepatuhan wajib pajak. Model analisis regresi linear berganda yang digunakan untuk menguji hipotesis ini adalah sebagai berikut.

Tabel 5 Hasil Analisis Linear Berganda

\begin{tabular}{|c|c|c|c|c|c|c|}
\hline \multirow{2}{*}{\multicolumn{2}{|c|}{ Model }} & \multicolumn{2}{|c|}{$\begin{array}{l}\text { Unstandardized } \\
\text { Coefficients }\end{array}$} & \multirow{2}{*}{$\begin{array}{c}\text { Standardized } \\
\text { Coefficients } \\
\text { Beta }\end{array}$} & \multirow[b]{2}{*}{$t$} & \multirow[b]{2}{*}{ Sig. } \\
\hline & & $\mathrm{B}$ & Std. Error & & & \\
\hline \multirow[t]{4}{*}{1} & (Constant) & $\begin{array}{r}17.9 \\
93\end{array}$ & 3.316 & & 5.426 & .000 \\
\hline & X1 Tax Amnesty & .698 & .176 & 1.039 & 3.956 & .001 \\
\hline & $\begin{array}{c}\text { X2 Kesadaran Wajib } \\
\text { Pajak }\end{array}$ & $\begin{array}{r}- \\
.115^{-}\end{array}$ & .146 & -.138 & -.790 & .437 \\
\hline & X3 Sanksi Pajak & $351^{-}$ & .162 & -.516 & -2.167 & .040 \\
\hline
\end{tabular}

berdasarkan Tabel 5 dapat dilihat persamaan linear berganda adalah:

$\mathrm{Y}=\alpha+\beta 1 \mathrm{X} 1+\beta 2 \mathrm{X} 2+\beta 3 \mathrm{X} 3+\mathrm{e}$

$\mathrm{Y}=17.993+0,698 \mathrm{X} 1-115 \mathrm{X} 2-351 \mathrm{X} 3+3.316$

Persamaan tersebut dapat dijelaskan sebagai berikut.

1) Nilai $\beta 1$ yang merupakan koefisien regresi dari variabel X1 (tax amnesty) adalah sebesar positif $(0,698)$ mempunyai arti bahwa tax amnesty mempunyai pengaruh terhadap kepatuhan wajib pajak. 
2) Nilai $\beta 2$ yang merupakan koefisien regresi dari variabel $X 2$ (kesadaran wajib pajak) adalah sebesar negative (-115) mempunyai arti bahwa kesadaran wajib pajak tidak berpengaruh terhadap kepatuhan wajib pajak.

3) Nilai $\beta 3$ yang merupakan koefisien regresi dari variabel $X 3$ (sanksi) adalah sebesar negative (-351) mempunyai arti bahwa kesadaran wajib pajak tidak berpengaruh terhadap kepatuhan wajib pajak.

\subsubsection{Uji Hipotesis}

1. Uji Koefisien Determinasi (R2)Nilai koefisian determinasi adalah antara nol dan satu. Nilai R2 yang kecil berarti kemampuan variabel-variabel independen dalam menjelaskan variasi variabel-variabel dependen sangat terbatas. Nilai yang mendekati satu berarti variabel-variabel independen memberikan hamper semua informasi yang dibutuhkan untuk memprediksi variasi variabel dependen.

Tabel 6 Koefisien Determinasi (R2)

Model Summary ${ }^{\mathrm{b}}$

\begin{tabular}{|c|c|c|c|c|c|}
\hline Model & $\mathrm{R}$ & R Square & $\begin{array}{l}\text { Adjusted R } \\
\text { Square }\end{array}$ & $\begin{array}{l}\text { Std. Error of } \\
\text { the Estimate }\end{array}$ & $\begin{array}{l}\text { Durbin- } \\
\text { Watson }\end{array}$ \\
\hline 1 & $.671^{a}$ & .450 & .387 & 1.24096 & 2.594 \\
\hline
\end{tabular}

Dari Tabel 6 dapat dilihat pada Model Summary kolom R adalah koefisien Pearson $(0,671)$ yang menunjukan tingkat hubungan antara variabel independen dan variabel dependen. Dan diketahui bahwa R Square adalah 0,450 atau 45\%. Angka 45\% mengartikan bahwa angka dalam kepatuhan wajib pajak dipengaruhi oleh tax amnesty, kesadaran wajib pajak dan sanksi pajak, sedangkan sisanya 55\% dipengaruhi oleh faktorfaktor lain yang tidak diteliti.

2. Uji t (t-test) ini dimaksudkan untuk mengetahui pengaruh secara parsial (individu) variabel-variabel bebas (tax amnesty, kesadaran wajib pajak dan sanksi pajak) terhadap variabel terikat (kepatuhan wajib pajak) atau menguji signifikansi konstanta dan variabel terikat. Hasil perhitungan Uji t dapat dilihat sebagai berikut.

Tabel 7 Uji t

Coefficients $^{\mathrm{a}}$

\begin{tabular}{|c|c|c|c|c|c|c|}
\hline & \multirow[b]{2}{*}{ Model } & \multicolumn{2}{|c|}{$\begin{array}{l}\text { Unstandardized } \\
\text { Coefficients }\end{array}$} & \multirow{2}{*}{$\begin{array}{c}\begin{array}{c}\text { Standardized } \\
\text { Coefficients }\end{array} \\
\text { Beta }\end{array}$} & \multirow[b]{2}{*}{$\mathrm{T}$} & \multirow[b]{2}{*}{ Sig. } \\
\hline & & $\mathrm{B}$ & Std. Error & & & \\
\hline \multirow[t]{4}{*}{1} & (Constant) & 17.993 & 3.316 & & 5.426 & .000 \\
\hline & X1 Tax Amnesty & .698 & .176 & 1.039 & 3.956 & .001 \\
\hline & $\begin{array}{l}\text { X2 Kesadaran } \\
\text { Wajib Pajak }\end{array}$ & -.115 & .146 & -.138 & -.790 & .437 \\
\hline & X3 Sanksi Pajak & -.351 & .162 & -.516 & -2.167 & .040 \\
\hline
\end{tabular}

a. Uji t antara tax amnesty (X1) terhadap kepatuhan wajib pajak (Y)

Dari Tabel 7 dapat dilihat bahwa untuk variabel tax amnesty, nilai signifikansinya adalah 0,01 $(0,01<0,05)$ ini menunjukan bahwa variabel tax Amnesty berpengaruh positif terhadap kepatuhan wajib pajak. t-hitung $=3,956$ dan $\mathrm{t}$-tabel $=1,708$ dan nilai signifikansi $0,01<0,05$; karena t-hitung $>$ dari t-tabel dan nilai sig $<0,05$ : maka dari 
hasil uji ini dinyatakan $\mathrm{H}$ ditolak sehingga $\mathrm{H}$ diterima artinya secara parsial tax amnesty berpengaruh positif terhadap kepatuhan wajib pajak.

b. Uji t antara kesadaran wajib pajak (X2) terhadap kepatuhan wajib pajak (Y)

Dari Tabel 7 dapat dilihat bahwa untuk variabel kesadaran wajib pajak, nilai signifikansinya adalah $0,437(0,437>0,05)$ ini menunjukan bahwa variabel kesadaran wajib pajak berpengaruh positif terhadap kepatuhan wajib pajak. t-hitung $=(-2.167)$ dan t-tabel $=1,708$ dan nilai signifikansi $0,437>0,05$; karena t-hitung < dari t-tabel dan nilai sig > 0,05: maka dari hasil uji ini dinyatakan $\mathrm{H}$ diterima sehingga $\mathrm{H}$ ditolak artinya secara parsial sanksi pajak tidak berpengaruh positif terhadap kepatuhan wajib pajak.

c. Uji t antara sanksi pajak (X3) terhadap kepatuhan wajib pajak (Y)

Dari Tabel 7 dapat dilihat bahwa untuk variabel sanksi pajak, nilai signifikansinya adalah 0,04 $(0,04>0,05)$ ini menunjukan bahwa variabel sanksi pajak berpengaruh positif terhadap kepatuhan wajib pajak. t-hitung $=(-790)$ dan t-tabel $=1,708$ dan nilai signifikansi $0,04<0,05$; karena t-hitung $<$ dari t-tabel dan nilai sig $<0,05$ : maka dari hasil uji ini dinyatakan $\mathrm{H}$ diterima dan $\mathrm{H}$ ditolak artinya secara parsial kesadaran wajib pajak tidak berpengaruh positif terhadap kepatuhan wajib pajak.

3 Uji F (kelayakan model) dimaksudkan untuk mengetahui pengaruh variabel-variabel independen (tax amnesty, kesadaran wajib pajak dan sanksi pajak) tehadap variabel dependen (kepatuhan wajib pajak). Hasil perhitungan Uji F adalah sebagai berikut.

\section{Tabel 8 Hasil Uji F}

\begin{tabular}{|c|c|c|c|c|c|c|}
\hline \multicolumn{7}{|c|}{ ANOVA $^{a}$} \\
\hline \multicolumn{2}{|r|}{ Model } & $\begin{array}{l}\text { Sum of } \\
\text { Squares }\end{array}$ & $d f$ & Mean Square & $\mathrm{F}$ & Sig. \\
\hline 1 & Regression & 32.760 & 3 & 10.920 & 7.091 & $.001^{\mathrm{D}}$ \\
\hline & Residual & 40.040 & 26 & 1.540 & & \\
\hline & Total & 72.800 & 29 & & & \\
\hline
\end{tabular}

Dari Tabel 8 dapat dilihat bahwa nilai F-hitung sebesar 7,091 dan F-tabel 2,74 dengan nilai signifikan pada tabel $0,001<0,05$. Maka dapat disimpulkan bahwa variabel tax amnesty, kesadaran wajib pajak dan sanksi pajak berpengaruh secara simultan terhadap kepatuhan wajib pajak.

\subsection{Pembahasan}

\subsubsection{Pengaruh tax amnesty terhadap kepatuhan wajib pajak}

Hasil pengujian menunjukan bahwa tax amnesty terhadap kepatuhan wajib pajak berpengaruh positif dan signifikan, yaitu pada tingkat signifikansi 5\%. Hasil tersebut menunjukan bahwa tax amnesty mampu memberikan pengaruh terhadap kepatuhan wajib pajak. variabel tax amnesty berpengaruh secara parsial terhadap kepatuhan wajib pajak, karena nilai signifikansi lebih kecil daripada 0,05. Hal ini mengindikasikan bahwa perubahan yang terjadi pada variabel tax amnesty akan berpengaruh signifikan terhadap kepatuhan wajib pajak. Hasil penelitian menunjukkan koefisien transformasi regresi sebesar 3,956, hal ini menunjukkan bahwa rasio tax amnesty memiliki pengaruh positif terhadap kepatuhan wajib pajak. Pengaruh positif yang ditunjukkan oleh tax amnesty 
mengindikasikan bahwa apabila kebijakan tax amnesty ditingkatkan maka kepatuhan wajib pajak akan mengalami peningkatan pula, begitupun sebaliknya. Hasil penelitian ini sesuai dengan hasil penelitian dari Ngadiman (2015) yang menunjukkan bahwa tax amnesty secara parsial berpengaruh positif dan signifikan terhadap tingkat kepatuhan wajib pajak dengan nilai signifikan lebih kecil dari 0,05 .

\subsubsection{Pengaruh kesadaran wajib pajak terhadap kepatuhan wajib pajak}

Hasil penelitian menunjukkan koefisien transformasi regresi sebesar (-790), hal ini menunjukkan bahwa variabel kesadaran wajib pajak tidak memiliki pengaruh positif terhadap kepatuhan wajib pajak. Penelitian ini sejalan dengan penelitian Suryandari (2016), yang mengungkapkan bahwa kesadaran perpajakan tidak berpengaruh terhadap kepatuhan yang diduga karena pada umumnya wajib pajak masih sinis terhadap keberadaan pajak. Dari beberapa hasil penelitian sebelumnya menunjukan bahwa tidak semua hasil penelitian menunjukan variabel kesadaran wajib pajak berpengaruh positif terhadap kepatuhan wajib pajak, begitu pula sebaliknya. Hal ini disebabkan karena Wajib Pajak di setiap tempat memiliki tingkat kesadaran melaksanakan tanggung jawabnya itu berbeda-beda, meskipun teori mengatakan bahwa kesadaran wajib pajak dapat mempengaruhi kepatuhan wajib pajak.

\subsubsection{Pengaruh sanksi pajak terhadap kepatuhan wajib pajak}

Hasil penelitian menunjukkan koefisien transformasi regresi sebesar $(-2,167)$, hal ini menunjukkan bahwa variabel sanksi pajak tidak memiliki pengaruh positif terhadap kepatuhan wajib pajak. Penelitian ini sejalan dengan penelitian Hananto (2015) yang menyatakan bahwa sanksi berpengaruh negatif terhadap kepatuhan membayar pajak dalam membayar pajak. Namun, penelitian ini tidak sejalan dengan penelitian yang dilakukan oleh Ngadiman dan Huslin (2015) menyatakan bahwa sanksi perpajakan berpengaruh positif terhadap kepatuhan wajib pajak. Hal ini disebabkan karena adanya persepsi wajib pajak yang terdaftar di KPP Pratama Manado tentang sanksi administrasi dan pidana yang masih ringan, hal ini menyebabkan sanksi tidak berpengaruh terhadap peningkatan kepatuhan wajib pajak oleh sebab itu perlu adanya tindak lanjut dari pemerintah.

\subsubsection{Pengaruh tax amnesty, kesadaran wajib pajak dan sanksi pajak secara simultan terhadap kepatuhan wajib pajak orang pribadi}

Hasil penelitian menunjukkan koefisien transformasi regresi sebesar 7,091, hal ini menunjukkan bahwa rasio tax amnesty, kesadaran wajib pajak dan sanksi pajak memiliki pengaruh secara simultan terhadap kepatuhan wajib pajak, dengan kontribusi sebesar $45 \%$. Variabel-variabel tersebut memiliki pengaruh positif yang signifikan terhadap kepatuhan wajib pajak orang pribadi. Besarnya pengaruh ketiga variabel adalah sebesar $45 \%$, hal ini mempunyai makna bahwa semakin tinggi rendahnya kepatuhan wajib pajak orang pribadi dipengaruhi oleh kebijakan tax amnesty, kesadaran wajib pajak dan sanksi pajak sebesar $45 \%$ sedangkan sisanya $55 \%$ dipengaruhi oleh faktor lain yang tidak diteliti dalam penelitian ini.

Berdasarkan hasil penelitian ini dapat dikatakan bahwa responden setuju kebijakan tax amnesty, kesadaran wajib pajak dan sanksi pajak berpengaruh positif terhadap kepatuhan wajib pajak orang pribadi. Untuk itu perlu ditingkatkan lagi ketiga variabel ini agar kepatuhan wajib pajak orang pribadi dapat lebih meningkat. 


\section{KESIMPULAN DAN SARAN}

\subsection{Kesimpulan}

Berdasarkan hasil pembahasan pada bab sebelumnya, maka dapat ditarik kesimpulan sebagai berikut.

1. Kebijakan tax amnesty berpengaruh positif yang signifikan terhadap kepatuhan wajib pajak orang pribadi. Pengaruh positif yang ditunjukkan oleh tax amnesty mengindikasikan bahwa kebijakan tax amnesty ditingkatkan maka kepatuhan wajib pajak akan mengalami peningkatan pula, begitupun sebaliknya.

2. Kesadaran wajib pajak tidak berpengaruh positif terhadap kepatuhan wajib pajak orang pribadi. Hal ini disebabkan karena Wajib Pajak di setiap tempat memiliki tingkat kesadaran melaksanakan tanggung jawabnya itu berbeda-beda, meskipun teori mengatakan bahwa kesadaran wajib pajak dapat mempengaruhi kepatuhan wajib pajak.

3. Sanksi pajak tidak berpengaruh positif terhadap kepatuhan wajib pajak orang pribadi. Hal ini disebabkan karena adanya persepsi wajib pajak yang terdaftarr di KPP Pratama Manado tentang sanksi administrasi dan pidana yang masih ringan, hal ini menyebabkan sanksi tidak berpengaruh terhadap peningkatan kepatuhan wajib pajak oleh sebab itu perlu adanya tindak lanjut dari pemerintah.

4. Kebijakan tax amnesty,kesadaran wajib pajak dan sanksi pajak berpengaruh positif secara simultan terhadap kepatuhan wajib orang pribadi.

\subsection{Saran}

Berdasarkan kesimpulan yang ada, maka dapat diberikan beberapa saran sebagai berikut

1. Bagi instansi terkait dalam hal ini KPP Pratama Manado, penerapan kebijakan tax amnesty dan sanksi pajak perlu ditingkatkan lagi agar supaya kepatuhan wajib pajak orang pribadi akan lebih meningkat karena tinggi rendahnya kepatuhan wajib pajak di pengaruhi oleh kebijakan dan sanksi yang diterapkan.

2. Bagi peneliti selanjutnya yang ingin melakukan penelitian terkait kepatuhan wajib pajak orang pribadi agar dapat menambah variabel-variabel lain diluar variabel ini sehingga dapat memperoleh hasil yang variatif dan sebaiknya menambah jumlah sampel agar memperoleh hasil penelitian yang lebih baik.

\section{DAFTAR PUSTAKA}

Agnes, 2015. Pengaruh Kesadaran Wajib Pajak, Sanksi Perpajakan dan Pemahaman Perpajakan terhadap Kepatuhan Wajib Pajak. Universitas Darma Persada.

Arum dan Zulaikha, 2012. Pengaruh Kesadaran Wajib Pajak, Pelayanan Fiskus, Dan Sanksi Pajak Terhadap Kepatuhan Wajib Pajak Orang Pribadi Yang Melakukan Kegiatan Usaha dan Pekerjaan Bebas (Studi di Wilayah KPP Pratama Cilacap). Diponegoro Journal Of Accounting, Vol.1 No.1. Hal 1-18.

Darussalam. 2015. Manfaatkan Pengampunan Pajak: Pahamai dan Manfaatkan Reinventing Policy. Inside Tax. Edisi 31.

Dewi dan Noviari, 2017. Pengaruh Kesadaran Wajib Pajak, Pelayanan Fiskus dan Sanksi Perpajakan pada Kemauan Mengikuti Tax Amnesty. Universitas Udayana Bali. Vol.19.2.Mei (2017). 1378-1405.

Diana. 2013. Konsep Dasar Perpajakan. Penerbit Aditama. Bandung. 
Elizabeth, 2016. Dampak Pelaksanaan Kebijakan Sanksi Pajak terhadap Kepatuhan Wajib Pajak Orang Pribadi di KPP Pratama Wilayah Kanwil Dirjen Pajak Daerah Istimewah Yogyakarta. Universitas Sanata Darma.

Fidel. 2015. Tindak Pidana Perpajakan \& Amandemen Undang-Undang $K U P, P P h, P P N, P e n g a d i l a n$ Pajak.Carofin Media. Kota Tangerang.

Hananto, Samudra Dhony. 2015. Pengaruh SPPT, Sanksi,Pendapatan Wajib Pajak terhadap Kepatuhan Wajib Pajak Bumi dan Bangunan. Skripsi Strata-1. Universitas Dian Nuswantoro Semarang.

Kuncoro, Mudrajad. 2013. Metode Riset untuk Bisnis \& Ekonomi Edisi 4. Penerbit Erlangga. Jakarta.

Mardiasmo. 2016. Perpajakan. Edisi Revisi, Yogyakarta: Penerbit Andi.

Mehmet Nar, 2015. The Effects of Behavioral Economics on Tax Amnesty. From : http://www. 0608mehmet@gmail.com/the-effects-of-behavioral-economics-on-taxamnesty.htm. [Last accessed on 2015 Mei 03].

Mipraningsih dan Suryandari, 2014. Pengaruh kesadaran perpajakan, Sikap Rasional, Sanksi, Pelayanan Fiskus dan Lingkungan terhadap Kepatuhan Wajib Pajak dalam Meningkatkan Penerimaan Pajak. Universitas muhammadiyah Yogyakarta.

Ngadiman dan Huslin, 2015. Pengaruh Sunset Policy, Tax Amnesty dan Sanksi Pajak terhadap Kepatuhan Wajib Pajak Orang Pribadi." Jurnal Akuntansi/Volume XIX, No. 02. http://journal.tarumanagara.ac.id/index.php/jakt/article/. Universitas Tarumanegara.

Nugroho, Andini \& Raharjo, 2016. Pengaruh Kesadaran Wajib Pajak dan Pengetahuan Perpajakan Terhadap Kepatuhan Wajib Pajak dalam Membayar PPh.

Puspareni, Purnamawati Wahyuni, 2017. Pengaruh Tax Amnesty, Pertumbuhan Ekonomi, Kepatuhan Wajib pajak dan Transformasi Kelembagaan Dirjen Pajak Terhadap Penerimaan Pajak Pada KPP Pratama Singajaya. Universitas Pendidikan Ganesha.

Ragimun. 2012. Analisis Implementasi Pengampunan Pajak. Badan Kebijakan Fiskal Kementrian RI.

Reny Sri Utami, 2013. Pengaruh Sanksi Perpajakan Terhadap Kepatuhan Wajib Pajak dan Implikasinya Pada Penerimaan Pajak. Universitas Komputer Indonesia.

Robert S. 2015. Pengaruh Sanksi, Kesadaran Wajib Pajak, Dan Kualitas Pelayanan PajakTerhadap Kepatuhan Wajib Pajak Bumi dan Bangunan. Universitas Negeri Padang.

Sugiyono. 2016. Metode Penelitian: Kuantitatif, Kualitatif dan R\&D. Alfabeta. Bandung.

Suwardjono. 2013. Akuntansi Pengantar. BPFE-YOGYAKARTA. Yogyakarta.

Thoifah, I'anatut. 2015. Statistika Pendidikan dan Metode Penelitian Kuantitatif. Madani. Malang.

Undang-Undang Republik Indonesia Nomor 28 Tahun 2007 tentang Ketentuan dan Tata Cara Perpajakan. 2013. Bandung: Fokusindo Mandiri.

Waluyo. 2011. Perpajakan Indonesia. Jakarta: Salemba Empat.

Wisegeek. 2014. What is tax amnesty? Available from: http://www. wisegeek.com/what-istax-amnesty.htm. [Last accessed on 2014 Nov 03]. 